\begin{tabular}{lcc}
\hline JURNAL ANALIS KESEHATAN & Klinikal Sains 8 (1) (2020) \\
UNIVERSITAS & KLINIKAL SAINS \\
http://jurnal.univrab.ac.id/index.php/klinikal & KUALAINS \\
\hline
\end{tabular}

\title{
Pengaruh Pemberian Ekstrak Lengkuas Putih (Alpinia galanga) Terhadap Pertumbuhan Escherichia coli
}

\author{
Tassya Alfiola dan Eliya Mursyida \\ Program Studi Pendidikan Dokter, Fakultas Kedokteran dan Ilmu Kesehatan, Universitas Abdurrab \\ Jl. Riau Ujung, No. 73, Pekanbaru \\ Email: eliya.zeya@yahoo.com
}

\begin{abstract}
Info Artikel
Abstrak

Sejarah Artikel:

Escherichia coli (E. coli) merupakan penyebab umum terjadinya infeksi saluran kemih (ISK). Salah satu tanaman yang sering dijadikan obat herbal adalah lengkuas putih (Alpinia galanga). Rimpang lengkuas putih diketahui memiliki senyawa antimikroba seperti flavonoid, kuinon, dan minyak atsiri yang terdiri senyawa

Diterima Januari 2020 Disetujui Februari 2020 Dipublikasikan Juni 2020 terpen dan fenol. Penelitian ini bertujuan untuk mengetahui pengaruh pemberian ekstrak lengkuas putih terhadap pertumbuhan E. coli. Penelitian ini merupakan penelitian eksperimental menggunakan post test only with control group dengan sampel lengkuas putih dengan konsentrasi 20\%, 40\%, 60\%, 80\%, dan 100\%, serta bakteri uji E. coli dengan metode Kirby-Bauer. Zona hambat yang terbentuk diukur menggunakan jangka sorong. Hasil yang diperoleh menunjukkan bahwa zona hambat tertinggi terdapat pada konsentrasi $100 \%$ dengan diameter rata-rata $5.61 \mathrm{~mm}$

Keywords: dan zona hambat terendah pada konsentrasi $20 \%$ dengan diameter rata-rata $1.25 \mathrm{~mm}$. Hasil uji fitokimia didapatkan bahwa lengkuas putih positif mengandung senyawa flavonoid, kuinon, terpen, dan fenol. Kesimpulan didapatkan bahwa adanya Escherichia coli; Urinary Tract Infections; KirbyBauer; white galangal pengaruh pemberian ekstrak lengkuas putih pada konsentrasi 20\%, 40\%, 60\%, 80\%, dan $100 \%$ terhadap pertumbuhan E. coli.
\end{abstract}

Kata Kunci: Escherichia coli, infeksi saluran kemih, Kirby-Bauer, lengkuas putih.

\begin{abstract}
Escherichia coli $($ E. coli) is a common cause of urinary tract infections (UTI). Of the plants that is often used as herbal medicine is white galangal (Alpinia galangal). White galangal rhizome is known to have antimicrobial compounds such as flavonoids, quinones, and essential oils consisting of terpenens and phenols. This study aims to determine the effect of white galangal extract on the growth of E. coli. This research is an experimental study using post test only with control group with samples of white galangal with a concentration of $20 \%, 40 \%, 60 \%, 80 \%$, and $100 \%$, as well as test bacteria E. coli with the Kirby-Bauer method. Inhibited zones formed are measured using calipers. The results obtained show that the highest inhibitory zone was at a concentration of $100 \%$ with an average diameter of $5.61 \mathrm{~mm}$, and the lowest inhibitory zone is at a concentration of $20 \%$ with an average diameter of $1.25 \mathrm{~mm}$. Phytochemical test results showed that the positives white galangal contains flavonoids, quinones, terpenes, and phenols. The conclusion was found that the effect of giving white galangal extract at a concentration of $20 \%, 40 \%, 60 \%$, $80 \%$, and $100 \%$ on the growth of E. coli.
\end{abstract}

Keyword: Escherichia coli, urinary tract infections, Kirby-Bauer, white galangal 
Alamat korespondensi: Jl. Riau Ujung, No. 73

ISSN 2338-4921

E-mail: eliya.zeya@yahoo.com

\section{PENDAHULUAN}

Infeksi Saluran Kemih (ISK) adalah infeksi yang terjadi akibat berkembang biaknya mikroba tertentu pada saluran kemih (Pontoan, Meila and Fariza, 2017). Keberadaan mikroba pada urin orang yang terinfeksi ISK didapatkan sekitar $10^{5} \mathrm{CFU} / \mathrm{ml}$ (Stamm, 2005). Diagnosis ISK ditegakkan berdasarkan anatomi, ISK terbagi menjadi 2 bagian yaitu ISK atas dan ISK bawah. Pada ISK atas terjadi pielonefritis akut dan rekuren, sedangkan pada ISK bawah tergantung dari gender, dimana pada perempuan menyebabkan sistitis dan pada laki-laki menyebabkan sistitis, prostatitis, epididimitis, dan urethritis (Sukandar, 2014).

Infeksi Saluran Kemih (ISK) merupakan infeksi yang umum terjadi di fasilitas perawatan jangka panjang di rumah sakit. Prevalensi ISK antara 25-50\% pada pasien wanita yang tidak memakai kateter dan sekitar 80\% terkait pemakaian kateter uretra lebih dari 2 minggu (Brusch, 2019). Mikroba penyebab terjadinya ISK antara lain bakteri dan jamur. Bakteri yang umum menyebabkan ISK adalah Escherichia coli (E. coli), dimana E. coli menyebabkan 70-95\% kasus ISK. E. coli merupakan bakteri Gram negatif, berbentuk batang pendek, dan motil. E. coli termasuk salah satu flora normal usus manusia dan bersifat oportunistik yang dapat menyebabkan terjadinya ISK. E. coli menginfeksi melalui 2 cara yaitu melalui aliran darah (infeksi hematogen) dan saluran kemih bawah (infeksi asenden). Sebagian besar E. coli menginfeksi dari saluran kemih bawah, yang berasal dari flora feses (Kumar, Abbas and Fausto, 2009; Sukandar, 2014; Brooks, Butel and Morse, 2018).

Beberapa antibiotik yang digunakan untuk pengobatan ISK diantaranya yaitu gentamisin, sulfametoksazol-trimetoprim, ampisilin, dan siprofloksasin (Brusch, 2019). Sekarang ini telah diketahui terdapatnya resistensi antibiotik terhadap E. coli, dimana pada ampisilin terjadi sebanyak $73 \%$, sulfametoksazol-trimetoprim sebanyak $56 \%$, siprofloksasin sebanyak $22 \%$, dan gentamisin sebanyak 18\% pada pasien yang dirawat di rumah sakit (Permenkes, 2015).

Salah satu tanaman yang dapat dijadikan sebagai obat herbal adalah lengkuas putih (Alpinia galanga). Secara tradisional dan turun temurun lengkuas dipakai oleh masyarakat diberbagai etnis sebagai obat untuk infeksi saluran cerna dan infeksi pada kulit (Kuntorini, 2018). Lengkuas putih diketahui memiliki kandungan senyawa kimia antara lain yaitu flavonoid (galangin), kuinon, dan minyak atsiri yang terdiri dari terpen (1,8 sineol, linalool, $\alpha$ terpineol, $\alpha$ pinen, $\beta$-pinen, borneol, trans-beta-caryopilen, trans-beta-farnesen) dan fenol (eugenol) (Wu et al., 2014; Kusriani and Zahra, 2015). 
Senyawa galangin bekerja dengan cara menyebabkan kebocoran kalium pada membran sel. Kuinon bekerja sebagai antioksidan serta dapat menghambat sintesis DNA dan RNA bakteri. Kombinasi 1,8 sineol, linalool dan $\alpha$ terpineol pada terpen menyebabkan kerusakan pada membran bakteri yang kemudian menyebabkan terbentuknya pori-pori pada membran sehingga menyebabkan komponen sel keluar dengan mudah yang akhirnya menyebabkan sel menjadi kolaps. Kombinasi borneol, trans-beta-caryopilen, trans-beta-farnesen dan senyawa minyak atsiri lainnya bekerja dengan berinteraksi terhadap lipopolisakarida dinding sel bakteri yang kemudian menyebabkan gangguan permeabilitas dan kebocoran dinding sel. Eugenol menyebabkan kebocoran protein dan lipid pada membran sel (Cushnie and Lamb, 2005; Oyedemi et al., 2009; Prakatthagomol, Klayraung and Okonogi, 2011; Rudiyansyah et al., 2012; Zengin and Baysal, 2014; Zaidel, Mian and Mohamadin, 2017).

Menurut penelitian sebelumnya, Kapitan (2017) menunjukkan bahwa ekstrak etanol 70\% lengkuas putih dari konsentrasi 25\%-100\% mampu menghambat pertumbuhan E. coli dengan diameter hambat yaitu $17.25 \mathrm{~mm}-25.72 \mathrm{~mm}$. Penelitian lainnya, yang dilakukan oleh Prakatthagomol, Sirithunyalug, \& Okonogi (2012) menunjukkan bahwa lengkuas putih mampu menghambat pertumbuhan $E$. coli dengan menggunakan $15 \mathrm{mg}$ ekstrak pada setiap sumur agar. Diameter hambat yang dihasilkan terhadap E. coli yaitu $11 \mathrm{~mm}$. Oleh karena itu, berdasarkan latar belakang di atas maka peneliti tertarik ingin meneliti tentang pengaruh ekstrak lengkuas putih (Alpinia galanga) terhadap pertumbuhan E. coli yang nantinya dapat digunakan sebagai herbal alternatif penyebab ISK.

\section{METODE}

Penelitian dilakukan secara in vitro menggunakan metode Kirby-Bauer (Cappuccino and Sherman, 2008) untuk melihat pengaruh lengkuas putih (Alpinia galanga) terhadap pertumbuhan Escherichia coli. Penelitian ini dilaksanakan pada bulan Februari - April 2019, bertempat di Laboratorium Bakteriologi Sekolah Tinggi Ilmu Farmasi Riau (STIFAR) dan Laboratorium Mikrobiologi Universitas Abdurrab Pekanbaru.

Alat-alat yang digunakan dalam penelitian ini adalah cawan petri, ose, kapas lidi, jangka sorong, beaker glass, pipet ukur, gelas ukur, hand scoon, blender, autoklaf, tabung reaksi, Bunsen, batang pengaduk, labu Erlenmeyer, kertas label, neraca analitik, marker, inkubator, rotary evaporator, corong, rak tabung reaksi, pinset, alumunium foil, mikropipet, vortex, dan hot plate. Bahan yang digunakan dalam penelitian ini adalah rimpang lengkuas putih yang diperoleh dari perkebunan rakyat di Kecamatan Tualang, isolat bakteri E. coli berasal dari Laboratorium Bakteriologi SMK Analis Kesehatan Abdurrab Pekanbaru, medium Mueller Hinton Agar (MHA), akuades, kertas saring, kertas cakram (blank disk), $\mathrm{NaCl} \mathrm{0,9 \% ,} \mathrm{etanol}$ 
96\%, alkohol 70\%, $\mathrm{BaCl} 21 \%, \mathrm{H}_{2} \mathrm{SO}_{4} 1 \%$, disk siprofloksasin, $\mathrm{Mg}, \mathrm{HCl}, \mathrm{NaOH},\left(\mathrm{CH}_{3} \mathrm{CO}\right)_{2} \mathrm{O}$, pereaksi Folin Ciocalteau.

\section{Prosedur Kerja}

Pembuatan Ekstrak Etanol 96\% Lengkuas Putih. Rimpang lengkuas putih dikeringkan hingga didapatkan sampel kering. Selanjutnya, dimaserasi menggunakan pelarut etanol $96 \%$ dengan perbandingan 1:10, lalu didiamkan selama 5 hari. Kemudian semua serat dikumpulkan dan diuapkan menggunakan rotary evaporator pada suhu $40^{\circ} \mathrm{C}$ sampai diperoleh ekstrak kental. Ekstrak yang diperoleh selanjutnya digunakan untuk uji fitokimia dan uji sensitivitas bakteri.

Uji Fitokimia. Uji flavonoid pada ekstrak lengkuas putih yaitu dengan menambahkan sedikit serbuk $\mathrm{Mg}$ dan $\mathrm{HCl}$ pekat sebanyak 1-3 tetes pada 1gr ekstrak lengkuas putih dalam tabung reaksi kemudian dipanaskan sebentar. Adanya flavonoid ditandai dengan terbentuknya warna merah, merah lembayung, orange dan hijau. Uji kuinon dilakukan dengan menambahkan 1-3 tetes $\mathrm{NaOH} 1 \mathrm{~N}$ pada $1 \mathrm{gr}$ ekstrak dalam tabung reaksi. Adanya kuinon ditandai dengan terbentuknya warna merah. Uji senyawa terpen dengan menambahkan $\mathrm{H}_{2} \mathrm{SO}_{4}$ pekat dan $\left(\mathrm{CH}_{3} \mathrm{CO}\right)_{2} \mathrm{O}$, masing-masing sebanyak 1-3 tetes pada $1 \mathrm{gr}$ ekstrak lengkuas putih dalam tabung reaksi. Adanya terpen ditandai dengan terbentuknya warna merah. Uji senyawa fenol dengan menambahkan larutan Folin Ciocalteau pada 1gr ekstrak dalam tabung reaksi. Adanya fenol ditandai dengan terbentuknya warna biru.

Pembuatan Konsentrasi Ekstrak. Ekstrak lengkuas putih dengan konsentrasi 100\% dibuat menjadi konsentrasi 20\%,40\%, 60\%, 80\% dengan menggunakan akuades berdasarkan dari perhitungan rumus pengenceran.

Uji Sensitivitas bakteri dengan metode Kirby-Bauer. Suspensi bakteri uji Escherichia coli disetarakan kekeruhan dan kepadatannya sesuai dengan standar McFarland 0,5\%. Selanjutnya, suspensi bakteri uji diswab pada medium MHA, kemudian diletakkan kertas cakram dan disk siprofloksasin sebagai kontrol positif dengan menggunakan pinset steril pada permukaan medium. Lalu kertas cakram ditetesi dengan ekstrak lengkuas putih dengan berbagai konsentrasi menggunakan mikropipet dan satu kertas cakram tanpa ekstrak sebagai kontrol negatif. Zona hambat (halo zone) yang terbentuk diamati dan diukur menggunakan jangka sorong dan dimasukkan ke dalam rumus.

Analisis Data. Data yang diperoleh disajikan dalam bentuk tabel dan gambar.

\section{HASIL DAN PEMBAHASAN}

Hasil uji fitokimia yang dilakukan pada beberapa senyawa aktif pada rimpang lengkuas putih (Alpinia galanga) didapat hasil pada Tabel 1 berikut: 
Tabel 1 Hasil Uji Fitokimia

\begin{tabular}{ccc}
\hline Uji Fitokimia & Hasil & Keterangan \\
\hline Flavonoid & $(+)$ & Warna orange \\
Kuinon & $(+)$ & Warna merah \\
Terpen & $(+)$ & Warna merah \\
Fenol & $(+)$ & Warna kehitaman \\
\hline
\end{tabular}

Hasil uji sensitivitas ekstrak lengkuas putih (Alpinia galanga) terhadap pertumbuhan $E$. coli dengan berbagai konsentrasi, serta kontrol negatif dan positif didapatkan hasil sebagai berikut (Tabel 2; Gambar 1).

Tabel 2 Hasil Uji Sensitivitas Ekstrak Lengkuas Putih Terhadap Pertumbuhan E. coli

\begin{tabular}{cc}
\hline Perlakuan & Mean $(\mathbf{m m})$ \\
\hline $20 \%$ & 1.25 \\
$40 \%$ & 2.03 \\
$60 \%$ & 3.51 \\
$80 \%$ & 4.56 \\
$100 \%$ & 5.61 \\
Kontrol (-) & 0 \\
Kontrol (+) & 20.15 \\
\hline
\end{tabular}
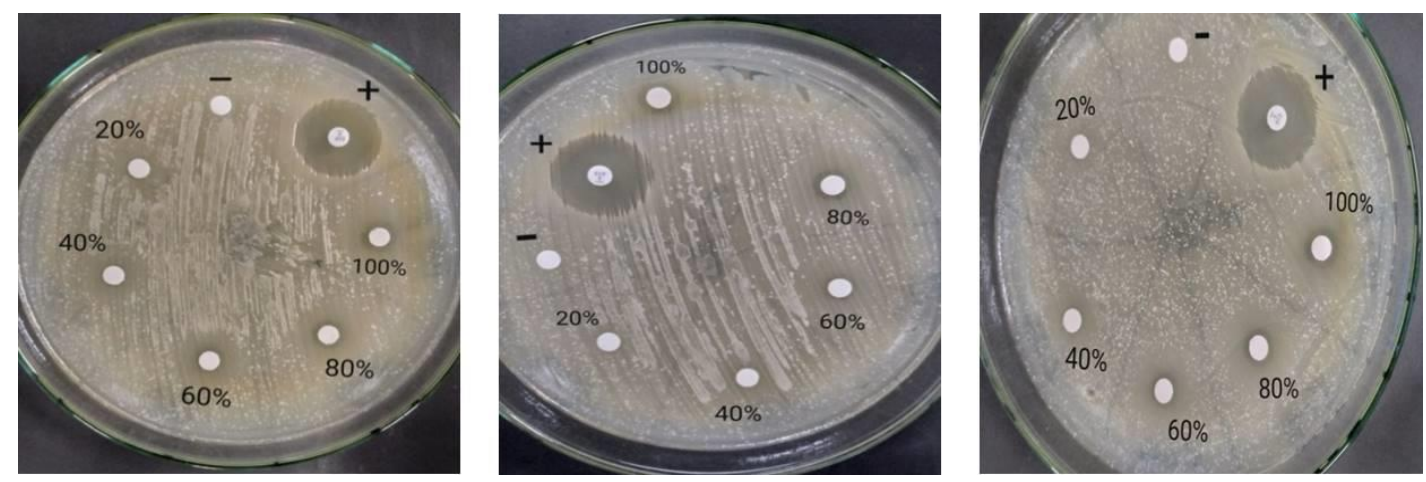

\section{Gambar 1 Hasil Uji Sensitivitas Ekstrak Lengkuas Putih Terhadap E. coli pada medium MHA. Keterangan: $(+)=$ kontrol positif, $(-)=$ kontrol negatif}

Berdasarkan hasil penelitian di atas, didapatkan bahwa ekstrak lengkuas putih mampu menghambat pertumbuhan E. coli dengan zona hambat tertinggi pada konsentrasi $100 \%$ dengan diameter rata-rata $5.61 \mathrm{~mm}$ dan terendah pada konsentrasi $20 \%$ dengan diameter rata-rata $1.25 \mathrm{~mm}$. Hal ini sesuai dengan penelitian yang dilakukan oleh Kapitan (2017) bahwa semakin tinggi konsentrasi ekstrak semakin tinggi zona hambat yang dibentuk maka semakin besar zona hambat yang dihasilkan. Berdasarkan kelompok aktivitas antibakteri menurut Davis Stout dalam (A'lana, Sari and Apridamayanti, 2017), konsentrasi 100\% pada penelitian ini dapat dikategorikan sedang, sedangkan konsentrasi 20\%, 40\%, 60\%, dan 80\% dikategorikan lemah. Terbentuknya zona hambat di sekitar kertas cakram disebabkan oleh beberapa senyawa 
antimikroba yang dimiliki lengkuas putih, antara lain yaitu flavonoid, kuinon, terpen, dan fenol (Tabel 1).

Flavonoid (galangin) merupakan senyawa yang berperan dalam merusak dinding sel bakteri, sehingga menyebabkan kebocoran kalium pada membran sel bakteri (Cushnie and Lamb, 2005). Senyawa kuinon sebagai antimikroba bekerja dengan cara berikatan pada asam nukleat bakteri, kemudian membentuk suatu kompleks yang mengganggu cetakan DNA, sehingga menghambat sintesis DNA dan RNA bakteri (Zaidel, Mian and Mohamadin, 2017).

Terpen merupakan komposisi utama minyak atsiri lengkuas putih. Senyawa terpen pada lengkuas putih yang terdiri atas kandungan utama berupa 1,8 sineol, linalool, $\alpha$-terpineol, $\alpha$ pinen, $\beta$-pinen, borneol, trans-beta caryopilen, trans-beta-farnesen (Wu et al., 2014; Khoerunnisa, 2015). Kombinasi 1,8 sineol, linalool dan $\alpha$-terpineol menyebabkan kerusakan morfologi dan struktural membran bakteri yang kemudian menghasilkan pori-pori pada membran sehingga menyebabkan komponen sel keluar dengan mudah yang akhirnya menyebabkan sel menjadi kolaps (Carson, Mee and Riley, 2002; Zengin and Baysal, 2014). Kombinasi borneol, trans-beta caryopilen, trans-beta-farnesen dan senyawa minyak atsiri lainnya bekerja dengan berinteraksi terhadap lipopolisakarida dinding sel bakteri yang kemudian menyebabkan gangguan pada permeabilitas dan kebocoran dinding sel bakteri sehingga menyebabkan lisis sel dan kematian sel (Prakatthagomol, Sirithunyalug and Okonogi, 2012). Jenis fenol pada lengkuas putih yaitu eugenol, dimana menyebabkan kebocoran protein dan lipid pada membran sel sehingga akhirnya menyebabkan lisis sel (Oyedemi et al., 2009).

Mekanisme senyawa antimikroba sesuai dengan pernyataan Brooks, Butel dan Morse (2018) bahwa kematian atau terhambatnya pertumbuhan bakteri akibat senyawa antimikroba yang memiliki mekanisme kerja dengan cara merusak membran atau dinding sel, denaturasi protein sehingga menyebabkan protein tidak berfungsi, hilangnya gugus sulfhidril bebas pada enzim dan kooenzim sel bakteri, kerusakan DNA, dan antagonis kimia.

Penelitian yang dilakukan oleh Parhusip, Gunawan dan Paramawati (2006) menunjukkan bahwa ekstrak lengkuas memiliki aktivitas antibakteri dengan diameter zona hambat sebesar $14.61 \mathrm{~mm}$ pada konsentrasi ekstrak tertinggi yaitu 50\% dengan metode sumuran. Hal ini sesuai dengan penelitian Dewi, Sri dan Wildiani (2017) yang menyatakan bahwa pada metode sumuran setiap lubang diisi konsentrasi ekstrak sehingga lebih homogen dan osmolaritas terjadi lebih menyeluruh sehingga lebih kuat untuk menghambat pertumbuhan E. coli. Menurut Distantina, Anggraeni dan Fitri, (2008) serta Bermawie et al., (2016) banyak faktor yang dapat mempengaruhi karakter morfologi, bobot, kandungan metabolit sekunder yaitu kadar minyak atsiri, mutu rimpang dan hasil ekstraksi sehingga mempengaruhi hasil penelitian. Faktor tersebut diantaranya yaitu faktor genetik, geografi tempat tumbuhan hidup, lingkungan yaitu curah hujan 
dan jenis pelarut yang digunakan. Kemungkinan lengkuas yang didapatkan di daerah Riau, pertumbuhannya tidak sebaik pertumbuhan lengkuas yang ditanam di daerah yang memiliki curah hujan tinggi. Lengkuas adalah tanaman yang membutuhkan cukup air pada masa pertumbuhannya terutama pada pertumbuhan awal. Bila tanaman lengkuas kekurangan air, maka tanaman menjadi stres dan akhirnya pertumbuhan tanaman menjadi terganggu dan menyebabkan berkurangnya kemampuan sebagai antimikroba.

Selain itu, E. coli merupakan bakteri Gram negatif yang memiliki komponen dinding sel yang lebih kompleks yang terdiri atas tiga lapisan yaitu lapisan luar (membran luar), lapisan tengah (lapisan peptidoglikan) dan lapisan dalam (membran sitoplasma) sehinggga menyebabkan zat antimikroba lebih sukar masuk ke dalam sel (Ernawati, 2011; Brooks, Butel and Morse, 2018; Rini, Rohmah and Widyaningrum, 2018).

\section{SIMPULAN}

Lengkuas putih mengandung senyawa aktif seperti flavonoid, tanin, fenol, terpen dan kuinon. Ekstrak lengkuas putih konsentrasi 100\% memiliki daya hambat terhadap pertumbuhan Escherichia coli dengan kategori sedang, sedangkan konsentrasi 20\%, 40\%, 60\%, dan 80\% kategori lemah.

\section{DAFTAR PUSTAKA}

A'lana, L., Sari, R. and Apridamayanti, P. (2017) 'Penentuan Nilai FICI Kombinasi Ekstrak Etanol Kulit Daun Lidah Buaya (Aloe vera (L) Burm.f) dan Gentamisin Sulfat Terhadap Bakteri Escherichia coli', Pharm Sci Res, 14(3), pp. 132-142.

Bermawie, N. et al. (2016) 'Karakter morfologi, hasil, dan mutu enam genotip lengkuas pada tiga agroekologi', Buletin Penelitian Tanaman Rempah dan Obat, 23(2), pp. 125-135.

Brooks, G. F., Butel, J. S. and Morse, S. A. (2018) Mikrobiologi Kedokteran: Jawetz, Melnick \& Adelberg. 27th edn. Jakarta: EGC.

Brusch, J. (2019) Urinary Tract Infection (UTI) and Cystitis (Bladder Infection) in Females. Available at: https://emedicine.medscape.com/article/233101-overview.

Cappuccino, J. G. and Sherman, N. (2008) Microbiology: A Laboratory Manual. 10th edn. Pearson.

Carson, C. F., Mee, B. J. and Riley, T. V (2002) 'Mechanism of Action of Melaleuca alternifolia (Tea tree) Oil on Staphylococcus aureus Determined by Time-Kill, Lysis, Leakage, and Salt Tolerance Assays and Electron Microscopy', Antimicrobial Agents and Chemotherapy. Am Soc Microbiol, 46(6), pp. 1914-1920.

Cushnie, T. P. T. and Lamb, A. J. (2005) 'Detection of Galangin-Induced Cytoplasmic Membrane Damage in Staphylococcus aureus by Measuring Potassium Loss', Journal of Ethnopharmacology. Elsevier, 101(1-3), pp. 243-248. 
Dewi, H. S., Sri, D. and Wildiani, W. (2017) 'Perbandingan Efek Ekstrak Buah Alpukat (Persea americana Mill ) Terhadap Pertumbuhan Bakteri Pseudomonas aeruginosa dengan Metode Disk dan Sumuran', (September), pp. 348-352.

Distantina, S., Anggraeni, D. R. and Fitri, L. E. (2008) 'Pengaruh konsentrasi dan jenis larutan perendaman terhadap kecepatan ekstraksi dan sifat gel agar-agar dari rumput laut Gracilaria verrucosa', Jurnal Rekayasa Proses, 2(1), pp. 10-14.

Ernawati, E. (2011) Pengaruh Ekstrak Rimpang Lengkuas (Languas galanga) Terhadap Pertumbuhan Bakteri (Staphylococcus aureus dan Escherichia coli) dan Jamur (Candida albicans). Makassar: Universitas Islam Negeri Alauddin Makassar.

Kapitan, L. A. V. (2017) 'Aktivitas Antimikroba Ekstrak Laos Putih (Alpinia Galangas) terhadap Bakteri Escherichia coli dan Salmonella sp', Jurnal Info Kesehatan. Politeknik Kesehatan Kementerian Kesehatan Kupang, 15(1), pp. 14-20.

Khoerunnisa, U. (2015) Studi Farmakognosi Rimpang dan Uji Aktivitas Antimikroba Minyak Atsiri Rimpang Lengkuas (Alpinia galanga L). Surabaya: Universitas Airlangga.

Kumar, V., Abbas, A. K. and Fausto, N. (2009) Dasar Patologis Penyakit. 7th edn. Jakarta: EGC.

Kuntorini, E. M. (2018) 'Botani Ekonomi Suku Zingiberaceae sebagai Obat Tradisional oleh Masyarakat di Kotamadya Banjarbaru', Bioscientiae, 2(1), pp. 25-36.

Kusriani, R. H. and Zahra, S. A. (2015) 'Skrining Fitokimia dan Penetapan Kadar Senyawa Fenolik Total Ekstrak Rimpang Lengkuas Merah dan Rimpang Lengkuas Putih (Alpinia galanga L.)', Prosiding SNaPP: Kesehatan (Kedokteran, Kebidanan, Keperawatan, Farmasi, Psikologi), 1(1), pp. 295-302.

Oyedemi, S. et al. (2009) 'The Proposed Mechanism of Bactericidal Action of Eugenol, $\propto-$ Terpineol and g-Terpinene Against Listeria monocytogenes, Streptococcus pyogenes, Proteus vulgaris and Escherichia coli', African Journal of Biotechnology. Academic Journals (Kenya), 8(7), pp. 1280-1286.

Parhusip, A. J. N., Gunawan, S. and Paramawati, R. (2006) 'Aktivitas Antibakteri Ekstrak Lengkuas (Alpinia galangal L. Swartz) Terhadap Bakteri Patogen Serta Stabilitasnya pada Pemanasan dan $\mathrm{pH}^{\prime}$. Universitas Pelita Harapan, Fakultas Teknik Industri, Jurusan Teknologi Pangan.

Permenkes, R. I. (2015) Program Pengendalian Resistensi Antimikroba di Rumah Sakit. Jakarta.

Pontoan, J., Meila, O. and Fariza, N. (2017) 'Pola Peresapan Antibiotik pada Pasien Infeksi Saluran Kemih di RSPAD Gatot Soebroto Jakarta', Social Clinical Pharmacy Indonesia Journal, 2(1), pp. 75-82.

Prakatthagomol, W., Klayraung, S. and Okonogi, S. (2011) 'Bactericidal Action of Alpinia galanga Essential Oil on Food-Borne Bacteria', Drug Discoveries \& Therapeutics. International Research and Cooperation Association for Bio \& Socio-Sciences ..., 5(2), pp. 84-89.

Prakatthagomol, W., Sirithunyalug, J. and Okonogi, S. (2012) 'Comparison of antibacterial 
activity against food-borne bacteria of Alpinia galanga, Curcuma longa, and Zingiber cassumunar', CMU J Nat Sci, 11(2), pp. 177-186.

Rini, C. S., Rohmah, J. and Widyaningrum, L. (2018) 'The Antibacterial Activity Test Galanga (Alpinia galangal) On The Growth of Becteria Bacillus subtilis and Escherichia coli', in IOP Conference Series: Materials Science and Engineering. IOP Publishing, p. 12142.

Rudiyansyah et al. (2012) 'Senyawa Antrakuinon yang Bersifat Antioksidan dari Kayu Akar Tumbuhan Mengkudu (Morinda citrifolia)', Bulletin of The Indonesian Society of Natural Products Chemistry, 12, pp. 9-13.

Stamm, W. (2005) Harrison's Principles of Internal Medicine. 16th edn. USA: Medical Publishing Division.

Sukandar, E. (2014) Infeksi Saluran Kemih Pasien Dewasa. 6th edn. Jakarta: Interna Publishing. $\mathrm{Wu}$, Y. et al. (2014) 'Composition of The Essential Oil from Alpinia galanga Rhizomes and Its Bioactivity on Lasioderma serricorne', Bulletin of Insectology. Department of Agricultural Sciences, 67(2), pp. 247-254.

Zaidel, N. D., Mian, V. J. Y. and Mohamadin, M. I. (2017) 'Iron (II) Complex of Anthraquinone: Synthesis, Structural Elucidation and Antimicrobial Activity', Malaysian Journal of Analytical Sciences, 21(5), pp. 1162-1167.

Zengin, H. and Baysal, A. H. (2014) 'Antibacterial and Antioxidant Activity of Essential Oil Terpenes Against Pathogenic and Spoilage-Forming Bacteria and Cell Structure-Activity Relationships Evaluated by SEM Microscopy', Molecules. Multidisciplinary Digital Publishing Institute, 19(11), pp. 17773-17798. 